\title{
VORMVERANDERING VAN KOLONIALISME IN DIE GESKIEDENIS
}

P. de Klerk

Departement Geskiedenis, Vaaldriehoekkampus, PU vir CHO

\section{ABSTRACT}

In this article it is argued that there are different forms of colonialisin and that some forms mainly featured in ancient and medieval times, while some forms belong to the modern and contemporary age. Forms such as tribal invasions, the moving of frontiers, political empires and trade colonies already existed during antiquity. Only from the sixteenth century onwards commercial empires were established world wide, giving rise to the development of settlement colonies. The large colonial empires which still existed at the beginning of the twentieth century have come to an end, but colonialism as such has not disappeared. Internal colonialism, which made its appearance with the development of the modern state system, and indirect colonialism should be regarded as the main forms of colonialism which exist today.

Die term kolonialisme dateer uit die periode van dekolonisasie na afloop van die Tweede Wêreldoorlog en is aanvanklik veral gebruik deur diegene wat hul beywer het vir die beëindiging van Westerse koloniale beheer in Afrika en Asië (Thornton, 1965; Fieldhouse, 1981:7). Die term het toe veral 'n negatiewe konnotasie gehad en is gereeld gebruik deur leiers en propagandiste in kommunistiese lande wat Westerse koloniale beheer as uitvloeisel van die kapitalistiese stelsel bestempel het en gekoloniseerde groepe tot verset teen die koloniale owerhede wou aanmoedig (vgl. Emerson, 1968:1). In wetenskaplike werke is die woord kolonialisme aanvanklik deur Marxistiese skrywers gebruik wat die negatiewe aspekte van die koloniale stelsels beklemtoon het, maar met verloop van tyd het die term 'n algemeen aanvaarde woord in wetenskaplike kringe geword om die hele verskynsel van koloniale beheer van een groep oor ' $n$ ander en van die onderhorigheid van een groep aan ' $n$ ander te omskryf.

Koers 53(1) 1988 
Definisies van kolonialisme soos dié van Kohn (1958:11), naanlik "... reduced to its barest outline colonialism is foreign rule imposed upon a people ...", en Emerson (1968:1), "... colonialism is the rstal)lishment and maintenance, for an extended time, of rule over an alien people that is separated from and subordinated to the ruling power...", bevat die kernelemente van die begrip soos wat dit meesal in hedendaagse wetenskaplike werke gebruik word. Sommige skrywers, soos Horvath (1972), wil die veld waarop die term kolonialisme van toepassing is, verder beperk en Horvath wil byvoorbeeld net gevalle waar 'n grool getal koloniste in ' $n$ gekoloniseerde gebied aanwesig is as gevalle van kolonialisme beskou. Wanneer daar, soos in die meeste Westers gekoloniseerde lande van Afrika die geval was, min of geen vestiging van koloniste was nie, wil hy die term imperialisme gebruik. Hierdie onderskeid hou egter nie rekening met die algemene gebruik van die woord kolonialisme nie. Die term het immers juis ontstaan om Westerse koloniale beheer in Afrika en Asië te omskryf. Imperialisme of ryksvestiging kan eerder as ' $n$ besondere vorm van kolonialisme gesien word, soos hieronder aangedui sal word.

Hoewel kolonialisme deur die meeste skrywers as "n algemene verskynsel gesien word wat in verskillende tydperke voorkom, skryf hulle byna uitsluitend oor Westerse kolonialisme in die moderne tyd. Van die talle werke wat in die afgelope jare oor imperialisme verskyn het, is daar verskeie met titels soos "teorieë van imperialisme" en "die ekonomie van imperialisme" (o.m. Thornton, 1965; Brown, 1974; Momusen, 1981; Etherington, 1984), maar dié boeke handel tog hoofsaaklik oor Westerse imperialisme van die negentiende en twintigste eeue. Daar word ook dikwels na die laat negentiende- en vroeg twintigste-eeusc era as die tydperk van kolonialisme verwys, terwyl die huidige tyd soins die nakoloniale era genoem word. Hiermee word geimpliseer dat kolonialisme tot 'n tydperk behoort wat nou verby is. Die feit dat Westerse imperialisme teen 1900 'n hoogtepunt beleef het en koloniale ryke van 'n groter omvang tot stand gekom het as wat vroeër dic geval was, betcken egter nie dat kolonialisme eie is aan 'n bepaalde tydvak nie. Die toenemende gebruik, ook in wetenskaplike kringe, van begrippe snos interne kolonialisme en neo-kolonialisme, om daarmec besondere verhoudinge wat vandag tussen bepaalde grocre en ook bepaalde state bestaan, aan te dui, dui daarop dat al meer besef word dat die 
sogenaamde era van kolonialisme nog nie verby is nie en dat dit as 'n algemene verskynsel gesien moet word wat in verstillende tydperke in verskillende vorme voorkorn.

Dit is my oogmerk met hierdie artikel om kortliks 'n aantal vorme van kolonialisme te onderskei en aan te dui dat sekere vorme vroeër algemeen voorgekom het en daarna van die toneel verdwyn het, terwyl ander vorme van meer resente oorsprong is, en dat kolonialisme dus in die loop van die wèreldgeskiedenis van vorm verander het. Hiermee word gepoog om onder meer groter duidelikheid te gee aan ' $n$ begrip soos interne kolonialisme, wat tans heelwat gebruik word, om aan te dui of dit wel as 'n vorm van kolonialisme beskou kan word, en ook om meer perspektief te gee op kolonialisme as historiese verskynsel.

Die indeling van kolonialisme in verskillende vorme wat ek in hierdie artikel mak, berus nie op 'n sistematiese analise van kolonialisme as verskynsel en van al die vorme wat in teorie moontlik is nie, maar slegs op ' $n$ vergelyking van gevalle van kolonialisme in die geskiedenis. Die verskillende vorme word van mekaar onderskei veral ter wille van groter duidelikheid, en bestaande begrippe soos volksverhuisings en ryke word gebruik om bepaalde vorme aan te dui. Dit sal ook blyk dat sommige gevalle van kolonialisme kenmerke van meer as cen vorm toon en dat alle gevalle van kolonialisme dus nie presies in 'n aantal kategorië̈ ingedeel kan word nie. Binne die bestek van hierdie artikel kan voorbeelde van die verskillende vorme nie uitgebreid beskryf word nie en kan net kortliks na bekende gevalle van kolonialisme in die geskiedenis verwys word.

\section{Volksverhuising}

Volksverhuisings is 'n bekende verskynsel in die wèreldgeskiedenis en daaronder word gewoonlik verstaan die verhuising van 'n groep, mecsal 'n hele volk of stam, van een gebied na ' $n$ ander waar die bestaande inwoners dan onderwerp word. Hoewel die begrip dus eintlik net betrekking het op ' $n$ verhuising, en by implikasie ook op die kolonisasie van 'n gebied, maar nie op die verdere oorheersing deur die 
koloniserende volk oor die gekoloniseerde bmvolking nic, sou dit gebruik kon word om 'n bepaalde vorn van kolonialisme aan te dui.

Die vroegste mense het, sover bekend uit die gebrelkige grgewens wat hieroor bestaan, hoofsaaklik 'n jagters - en versamelaarsbestaan gevoer en soms van een gebied na $n$ ander getrek. Die uitbreidingsbeweging van mense oor die aarde het waarskynlik eer's begin nadat mense die kuns bemeester het om grootwild te jag en klere wat as beskerming teen wisselende klimaatstoestande kon dien, begin dra is (vgl. Hawkes, 1976: 21-23; McNeill, 1978: 3-4). Teen 8000 v.C. was alle vastelande waarskynlik reeds bewoon. In hierdie vrocë periode van verhuising is dus hoofsaaklik onbewoonde gebiede binnegedring. As swakker grompe deur sterker groepe met beter wapens bedreig is, was daar vir hulle die moontlikheid om weg te trek, en die beskikbaarheid van groot onbewoonde gebiede het waarskynlik meegebring dat dic onderwerping van een groep deur ' $n$ ander nie baie algemeen voorgekom het nie.

Die toename van die wèreldbevolking, wat gepaard gegaan het met die aanvaarding van landbou en veeteelt as bestaanswyse, het daartoe gelei dat volksverhuisings in groter mate die onderwerping van groepe meegebring het. Dit was veral veeherdergroepe wat 'n nomadiese bestaan gevoer het wat dikwels van een gebied na $n$ ander beweeg het en onk die gebiede waar die gevestigde landbougroepe gewoon liet, binuegeval en gekoloniseer het. In die Nabye Ooste het, nadat die eerste beskawings in die Nylvallei en in Mesopotamië ontstaan het, ver'skeic invalle van nomadiese groepe uit die omliggende steppe- en woestyngetiede plaasgevind. Hierby is beskawings vernietig, maar dit het daarna soms juis tot nuwe bloei gelei, deurdat die oorheersers die kultuur van die onderworpe groepe oorgeneem en voortgesit het. Ook in Europa was daar sedert die vroegste tye verskeie aanvalle van nomadiese groepe warhy vroeëre invallers wat in ' $n$ bepaalde gebied gevestig geraak het, self wcer deur nuwe invallers onderwerp is. Hierdie invalle het voortgeduur tot diep in die Middeleeue, toe groot dele van Europa nog deur Mongoolse groepe uit Asië verower is. In Afrika het volksverhuisings nog tot in die vorige eeu voorgekom. Ook vandag nog is daar nomadiese groepe, onder meer in die Sahara- en Sahelgebied wat deur die ernstige droogtetoestande van die afgelope jare verplig is om na nuwr gebinde to trek. Hierdie volksverhuisings van ons eie tyd gann egter nie menr 
gepaard met onderwerping van groepe nie en is slegs migrasiebewegings. In die wêreld van vandag het die nomade 'n verdwynende kategorie geword (vgl. Weissleder, 1978; Khazanov, 1984) en is daar min moontlikhede dat hulle nuwe gebiede kan verower. Volksverhuisings is waarskynlik die vorm van kolonialisme wat die meeste in die geskiedenis voorkoun (hoewel oor min van al die verhuisings wat plaasgevind het meer as enkele gegewens bestaan), maar tans het daar 'n einde aan hierdie vorm van kolonialisme gekom.

\section{Ryke}

Die vestiging en voortbestaan van ryke is ook ' $n$ baie ou vorm van kolonialisme, hoewel nie so oud soos volksverhuisings nie. Dịe term (Engels ryk) word gewoonlik gebruik wanneer 'n maghebber en sy volgelinge, of 'n groep en hul leier, hul mag vestig oor 'n gebied en daarby mense onderwerp wat nie deel uitmaak van hul eie groep nie (vgl. Armstrong, 1982:131; Doyle, 1986:19, 30, 45). Die term imperialisme dui op die strewe, en ook die uitvoering daarvan, om 'n ryk te vestig (vgl. Koebner en Schmidt, 1960). Die verhuising van 'n groep van een gebied na ' $n$ ander speel nie noodwendig ' $n$ rol by ryksvestiging nie; in die meeste gevalle is ryke gestig deurdat 'n bepaalde groep of volk omliggende gebiede onderwerp, mar self hoofsaaklik in sy eie gebied bly woon het.

Die meeste ryke van die geskiedenis het uit aaneengeslote gebiede bestaan en slegs die groot Westerse koloniale ryke, wat vanaf die sestiende, maar veral eers in die negentiende eeu tot stand gekom het, het uit gebiede wat oor verskillende dele van die wèreld versprei was, bestaan en die moederland was dus deur die see, asook deur ander state, van gekoloniseerde gebiede geskei. Hoewel soms slegs dié ryke koloniale ryke genoem word, is alle ryke warin een groep oor ander heers, eintlik koloniale ryke, en is daar behalwe vir die geografiese skeiding tussen ryksdele, geen wesenlike verskil tussen oorsese koloniale ryke en ander ryke nie (vgl. byvoorbeeld die Russiese ryk, wat uit 'n aaneengeslote gebied bestaan het, maar in dieselfde tyd as die ander Westerse ryke ontstaan het). 
Ryksvestiging lei nie altyd daartoe dat in groot anntal mense van die dominerende groep in die verowerde gebied gain woon nie. Amistenare, soldate en handelaars wat na die gebiede gant, hly ciliwels net tydelik daar en daar is dus 'n voortdurende wisseling van irde van die koloniserende groep in die gekoloniseerde gebied. Dit kom egter ook reeds sedert die Antieke tyd voor dat die koloniseerders in die verowerde gebied sentrums stig waarin setlaars of koloniste uit die kerngebied of moederland hul permanent vestig. Dit is hierdie sentrums van koloniste binne ryke wat deur die Romeine kolonies genoem is.

Reeds in die vroeë fase van hul ryksvestiging, toe Italië onderwerp is, het die Romeine die beleid gehad om kolonies van setlaars in die verowerde gebiede te stig. So 'n kolonie het gewoonlik bestaan uit 'n ommuurde stad waar die setlaars gewoon het, saam met die omliggende grondgebied wat aan hulle toegeken en deur hulle bewerk is. Sulke kolonies was veral van militère waarde vir die Romeine en was middele om hul gesag in die verowerde gebiede te vestig. Aanvanklik was dit veral Romeine (dus mense uit Rome) wat in die kolonies gaan woon het, maar later was dit ook mense uit ander gebiede wat onder Romeinse gesag was, sodat die koloniste dus nie altyd werklik lede was van die koloniserende groep nie (vgl. Salmon, 1969). Later is ook buite Italië kolonies gestig warin veral setlaars uit Italië gewoon het, en hulle het in belangrike rol in die romaniseringsproses gespeel.

In die Westerse koloniale ryke in Asië en Afrika van die negentiende en vroeë twintigste eeue is ook Westerse stede gestig waarin koloniste gaan woon het, en wat sentra van ekonomiese ontwikkeling geword hel. Soos in die Romeinse kolonies, het lede van die gekoloniseerde bevolking na die sentra gegaan, daar in noue aanraking met die kultuur van die koloniste gekom, en is soms in die koloniserende groep opgeneem.

Benewens koloniste uit die moederland of kerngebied, is soms ook mense uit ander dele van die ryk, of selfs uit ander lande, na die verowerde gebiede gebring, veral om ekonomiese redes. Bekende voorbenlde is die swart slawe wat uit Afrika deur die Portugese, Spanjaarde en Engelse na hul koloniale ryke in Amerika gebring is, en die lindiërs wat as arbeiders deur die Britte in verskillende dele van hul ryk - Birma, Maleisië, Natal, Kenia - ingevoer is (vgl. Lemon, 1980). In sulke gevalle. -126 - 
het ryksvestiging dus nie net die koms van 'n nuwe heersersgroep mengebring nie, maar ook van ander groepe, wat, soos die oorspronklike inwoners, 'n ondergeskikte posisie in die ryk beklee het.

Soms het ook mense uit die gekoloniseerde gebiede na die kerngebied van die ryk verhuis, sodat die oorspronklike geografiese skeiding tussen die etniese groepe binne die ryk al meer verswak is en soms verdwyn het. Samelewings waar verskillende etniese groepe deurmekaar woon, is dus gevorm, maar in enkele gevalle, soos die Romeinse ryk, het 'n proses van integrasie daartoe gelei dat uiteindelik 'n byna homogene samelewing tot stand gekom het, (vgl. Doyle, 1986:82-103). Daarmee is die koloniale proses voltooi en was die ryk dus nie meer werklik 'n koloniale ryk, in die $\sin$ wat dit hierbo omskryf is, nie.

Die Britse koloniale ryk, die grootste ryk in die geskiedenis sowel wat oppervlakte as bevolking betref, en die ander Europese ryke, het in die twee dekades na die Tweede Wêreldoorlog van die toneel verdwyn. Enkele ryke, in besonder die Russiese en Chinese ryke, het egter bly voortbestaan, hoewel met 'n nuwe staatsvorm waarin die onderworpe volke in teorie gelyke regte geniet. Hierdie ryke word vandag meesal as gewone state gesien en integrasieprosesse soos in die vroeëre Romeinse ryk is moontlik besig om daartoe te lei dat hulle hul karakter as ryke verloor. Anders as in die geval van volksverhuisings kan van ryke tog nog nie gesè word dat dit 'n vorm van kolonialisme is wat definitief tot die verlede behoort nie.

\section{Grensverskuiwing}

Die konsep van grensverskuiwing is vir die eerste keer duidelik na vore gebring deur die Amerikaanse historikus F. Turner wat in $1895 \mathrm{sy}$ bekende hipotese oor die invloed van die frontier op die vorming van die Amerikaanse nasionale karakter geformuleer het.

Sedertdien het ' $n$ hele dantal werke verskyn warin grensverskuiwing in Amerika, maar ook in lande soos Australië en Suid-Afrika behandel is (o.m. Billington, 1949; Webb, 1952: Lamar en Thompson, 1981). Dit is egter 'n verskynsel wat baie ower is as die tydperk van Westerse 
kolonialisme en het waarskynlik reeds by die vroegste landbougemeenskappe, duisende jare gelede, voorgekom. In China het die geleidelike verspreiding van landbouers vanaf dio knerngebied na die minder ontwikkelde dele in die suide en noorde moontlik al in die vyfde millennium voor Christus begin. In die eerste ses ecue na Christus het miljoene boere warskynlik aan die uitbreidingsproses deelgeneen (Lee, 1978). Grensverskuiwing was ook 'n algemene verskynsel in die Middelecuse feodale samelewing van Wes-Europa. Randgebiede soos Wallis en Skotland in die weste en die gebied oos van die Oder in die ooste is geleidelik binnegedring. In die ooste is bosse uitgekap en grond bewerkbaar gemaak deur Duitse boere en is die Baltiese en Slawiese volke uitgeroei, en deels geassimileer. In die Rusiese geskiedenis het grensverskuiwing ook 'n baie groot rol gespeel en gelei tot die kolonisasie van 'n geweldige groot gebied - Siberië - gedurende die sewentiende tot negentiende eeue.

Onder grensverskuiwing as vorm van kolonisasie en kolonialisme moet dus verstaan word die verhuising van inwoners van 'n gebied na 'n aangrensende gebied, waar hulle tussen die bestaande inwoners inbeweeg en hulle uiteindelik onderwerp. Die verskuiwing van ' $n$ land se inwoners na 'n aangrensende gebied bring meesal mee dat die regering van die land ook sy grense uitbrei en dat die vroeëre aangrensende gebied nou ' $n$ gekoloniseerde gebied word. Ander's as by 'n volksverhurising gaan dit hier nie om die verskuiwing van ' $n$ hele volk of stam nie, en die koloniseerders is in hierdie geval meesal nie jagters- of nomadiese groepe nie, maar dikwels boere, wat soins wel 'n halfnomadiese leefwyse het, en soms ook feodale here en handelaars. Grensverskuiwing verskil van ryksvestiging veral daarin dat die inisiatief in die kolonisasie nie geneem word deur politieke leiers of maghebbers nie, maar deur grenshewoners wat dikwels teen die wil van hul owerheid optree. llowel owerhede die beweging van hul onderdane oor die landsgrense soms probeer verhinder, het hulle nie altyd die mag om dit te keer nie, en moet hulle soms met verloop van tyd hul by hierdie optrede neerle en dis landsgrense verskuif. Wanneer die owerhede nie hul gesag oor die gnkoloniseerde gebied uitbrei nie, lei dit soms tot die totstandkoming van nuwe politicke eenhede in daardie gebied. 
Hoewel die proses van grensverskuiwing in elke goval sy besondere kenmerke liet, kan enkele algemene fases tog minerskei word. In die eerste fase, voordat die eerste koloniste die nuwe gebied binnedring, is daar twee aparte samelewings wat elk in sy cie gebied woon hoewel wedersydse kontak en kultuurbeïnvloeding dikwels reeds plaasvind.

In die tweede fase het 'n klein groepe lede van die eerste samelewing die tweede samelewing binnegedring. Hulle is immigrante wat hul egter nie aan die owerhede van die samelewing onderwerp nie en wat dikwels met hul vreemde en soms hoër kultuur die hele samelewing beïnvloed. Die eerste koloniste is soms vrybuiters wat hul aan geen gesag onderwerp nie en ook juis dic owerheid in hul eie land wil ontvlug, en hul koms lei dikwels tot onrus in die hele grensgebied (vgl. Galbraith, 1960). In die volgende fase is daar meer koloniste, wat die samelewing wat hul binnegedring het, baie ontwrig, soms feitlik vernietig, sodat 'n nuwe samelewing waarin die koloniste domineer, tot stand kom. Die onrspronklike inwoners het in die proses groot dele van die grondgebied wat hul besit het, verloor (soms deur ruiltransaksies, dikwels ook deur verowering). In die laaste fase, wanneer die gekoloniseerde grbied deur die regering van die koloniste se herkomsland onder sy gesag gebring word, of wanneer die koloniste 'n eie owerheid daarstel, bebou die groepe wat verdring is soms aanvanklik nog in klein enklaves hul onafhanklikheid, mar koin uiteindelik tog onder die gesag van die koloniserende owerheid. Grensverskuiwing kan, wanneer daar 'n groot gebied is wankheen uitgebrei kan word, soos in die V.S.A. en Siberië die geval was, 'n lang proses wees waar telkens weer 'n nuwe gebied 'n grensgebied word en gekoloniseer word. Grensverskuiwing kan slegs plaasvind war die gebied oorkant die oorspronklike grens dun bevolk is of die inwoners primitief of sonder 'n goeie sentrale gesag is, sodat hulle die binnedringing van vreemdelinge in hul gebied nie kan teëlıou nie. In die huidige wèreld met duidelik afgebakende grense tussen state, wat meesal ook goed bewak word, is die geleidelike beweging van boere en handelaars oor grense heen feitlik nie meer moontlik nie, en kom hierdie vorm van kolonialisme nie meer voor nie.

Handelskolonies en handelsryke 
Die vestiging van handelskolonies en handelsmye krm, sons dir vorme van kolonialisme wat hierbo reeds bespreek is, reeds in sie (Mulhrid vnor, en is so oud soos die begin van die halldel, in besonder hilldel per stip. Die seevarende handelaars het vaste handelsposte in guhirdo wara liul handel gedryf het, gestig. waar sommige handelaars hul dan ook permanent gevestig het. Hierdie poste is soms gestig in onbowoonde grobiede of in gebiede warvan die inwoners verder die binneland ingedryf is of ook in gebiede met inwoners wat redelik maklik onderwerp kon woref. Vanuit die handelsposte is soms ook omliggende gebiedn onderwerp. hoewel die handelaars meesal nie daarin geinteressecrd was on groot gebiede te beheer nie. Die handelskolonies was soms outonomo gemeenskappe wat deur die koloniste self bestuur is, maar soms was hul ondergeskik aan die regering van die moederland (of moedorstad). Stato wat verskeie handelskolonies gehad het, soos Fenicië in dic Antieke Tycl of, in die Middelecue, Venesië en Genua, kan as handelsryke beskou word. Strategiese vestigings wat nie direk handelsposte was rie, maiar van belang om handelsryke te beskerm, het soms ook doel van handelsryke gevorm.

Handelsposte is soms ook gestig in gebiede wat onder belieer van die owerheid van die gebied gebly het. Sulke handelsposte was dus nie werklik handelskolonies nie, al word hulle soms so genoem. Ilandelsvolke, soos die Jode en Armeniërs, het in die afgelope tweeduisend jaar oor groot dele van die wèreld versprei en aparte wyke in talle stede bowoon. Soms het hulle daar beperkte seggenskap oor eic sake gehad, maar was tog steeds ondergeskik aan die regeerders van die lande waarin hul gewon het, en daar kan in hulle geval dus nie van handelskolonies of handelsryke gepraat word nie (vgl. Curtin, 1984:182-206). In sommige gevalle het sulke handelaars baie groot outononie gekry, smos die Westerse handelaars in China dic negentiende en vroeë twintigste ceue, wat hul eie polisie en geregshowe gehad het, sodat dic Britse, Franse, Duitse en ander groepe elk feitlik 'n stat binne 'n staat gevorm het.

Die inisiatief in die vestiging van handelskolonies is dikwels genorm deur. individuele handelaars en handelsmaatskappye. In baie gevalle hort onafhanklike handelstede self koloniste uitgestutu om kolonics to stigy. Dit het veral voorgekom by die Grickse stede wat vanal die aysle enu voor Christus 'n groot antal kolonies in die oostelike Middellandsesac- 
en die Swartseegebied gestig het. Hierdie kolonies is nie almal net om handelsredes gestig nie, maar ook ondat met die toename in bevolking van die stede sommige inwoners 'n beter lieenkone en landbougrond in 'n nuwe gebied gesoek het en dan uitgewyk het na 'n landstreek war hulle 'n eie stadsgemeenskap volgens die nodel van hul moederstad gestig het. Hierdie nuwe stede het soms polities afhanklik gebly van die moederstad, maar soms ook self onafhanklike stadstate geword (vgl. Haınmond, 1967:114). Sulke kolonies pas dus nie heeitemal in die patroon van handelskolonies soos in hierdie afdeling geïdentifiseer nie.

In die vestiging van die groot Westerse handelsryke van die vyftiende, sestiende en sewentiende eeue het regerings 'n belangrike rol gespeel. Die oudste handelsryke, dié van Portugal en Spanje, is geheel en al deur die optrede van dié lande se regerings daargestel, maar in die geval van die Nederlandse, Britse en Franse handelsryke, is dic inisiatief geneem deur privartmatskappye wat 'n alleenreg van hul regering verkry het om in ' $n$ bepaalde wèrelddeel handel te dryf, en ook deur kolonies te stig en te bestuur. Die oorspronklike koloniste in die handelskolonies is steeds aangevul deur nuwe immigrante uit die moederland, en soms is immigrante uit ander lande ook as slawe of werkers ingevoer, sodat ' $n$ kosmopolitiese bevolking in hierdie kolonies tot stand gekom het.

Handelskolonies het soms eeue lank as klein enklaves binne ander gebiede bly voortbestaan en 'n eie samelewing en kultuur, wat verskil het van die onliggende gebied, behou. In verskillende gevalle, soos die Griekse kolonies in Suid-Italië en Noord-Afrika, het handelskolonies 'n sterk kulturele invloed op die omliggende gebiede uitgeoefen. Soms is die omliggende gebiede ook onderwerp en gekoloniseer, en het die handelsryke oorgegann in territoriale ryke (bv. Brits-Indië) of in vestigingskolonies, soos onder meer gobour het met die Nederlandse kolonie aan die Kaap.

Enkele handelskolonies, onder meer Gibraltar en Hongkong, bestaan vandag nog en ook Walvisbaai as 'n Suid-Afrikaanse cnklave in SuidwesAfrika, kan as 'n oorblyfsel gesien word van 'n tydperk toe sulke klein kolonies 'n algemene verskynsel was, maar dit is duidelik dat hierdie vorm van kolonialisme nie meer pas in die huidige patroon van internasionale verhoudinge nie. 


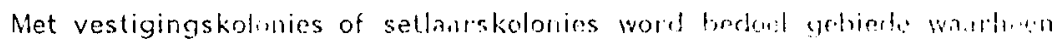
'n groot aantal mense wit die morderland (on sons bok uit amder lumbe) verhuis sodat die koloniste daar nie net 'n clitegroep in die snmelewing vorm nie, maar in nuwe samelewing vestig warrin dic oorspronklike bewoners meesal ook opgeneem word, maar warin hut dan mensal slrus 'n randgroep word. So 'n kolonie kan eintlik net tot stame kom in redelik dun bevolkte gebiede.

As die vernaamste verskil tussen die totstandkoming van 'n vestigingskolonie en in volksverhuising kan beskuu word dat die koloniste of setlaars nic in nomadiese groep is nie en meosal eers madat die gotied onder gesag van die moederland gebring is en oor 'n lang periode no dio kolonie emigrecr. 'n Vestigingskolonie kan deel vorm van 'n ryk, mar het tog besondere kenmerke wat nie altyd in 'n ryk voorkon nie. Darr is ook ooreenkounste met handelskolonies. Baie vestigingskolonies isons die Kaapkolonie) het as handelskolonie begin, daarna oor 'n groter gebied uitgebrei en groot getalle immigrante uit die moederland opgeneen. Die proses van uitbreiding van die handelskolonic se grense het dikwels die karakter van grensverskuiwing, soos hicrbo bespreek, mar. grensverskuiwing as vorm van kolonisasie kom nie net by vestigingskolonies voor nie.

Hoewel daar in die Oudheid kolonies was wat as vestigingskolonies beskou kan word, soos die Griekse kolonies in Suid Italië, was dit log slegs vestiginge op klein skaal. Die era van vestigingstiolonins hrt eintlik eers in die sestiende eeu angebreek toe die Europeèrs die dun hevolkte vasteland van Amerika ontdek het, en daarna ook die suidwrestelikr rleel van Afrika en nog later Australie. Sedert die sestiende onen hat milioene mense uit Europa na hierdie gebiedo verhuis en Westerse smmolowings danr tot stand gebring. Hulle getalle is verder anngevul deur slawe wat uit Afrika ingevoer is on sedert die negentiende ecu dour immichante uil die dig bevolkte lande van Oos-Asic̈. Interessant is dat na die afskaffincl van slawerny vroeëre slawe in dele van Wes-Afrika (1.iberiö. Sicra l comre en Gaboen) hervestig is en so nuwe vestigingskolonies in Afrikn tot stand gebring is. 'n Vestigingskolonie met in besondore karakter wit ners in die twintigste eeu ontstann het, is israrl war entole miljocms -132 . 
afstammelinge van die llebreërs, wat eeue gelede in die gebied gewoon het, uit alle dele vall die wèreld hulle gaan vestig het en die inheemse hevolking grotendeels verdring het.

Die totstandkoming van vestigingskolonies het gelei tot in radikale herverspreiding van die wèreldbevolking, waardeur die Europeërs 'n baie groter gebied vir bewoning vir hulself verkry het as wat hul oorspronklik gehad het. Hoewel die vestigingskolonies in die sewentiende en agtiende eeve deur die Europese moederlande hoofsaaklik as slegs van ekonomiese belang vir die Furopese kerngebied gesien is en hul afgeleë gebiede was wat nie ' $n$ belangrike rol in die ontwikkeling van die Westerse Beskawing gespeel het nie, het sommige van die kolonies uitgegroei tot belangrike state wat magtiger geword het as die ou Europese moederstate, en een van hulle, die Verenigde State van Amerika, het naas die Sowjet-Unie, die magtigste en kultureel invloedrykste land ter wêreld geword.

Vestigingskolonies as vorm van kolonialisme behoort dus tot die navyftiende-eeuse periode in die wêreldgeskiedenis. Terwyl daar vandag min dun bevolkte gebiede in die wêreld oor is, lyk dit onwaarskynlik dat nuwe vestigingskolonies nog in die toekoms tot stand kan kom. Die moontlikheid kan egter nie heeltemal uitgesluit word nie, veral as in gedagte gehou word dat die bevolking van sommige lande in steeds verdere afname toon.

Magsoorname deur immigrante

Daar is verskeie gevalle in die geskiedenis waar " groep mense wat aanvanklik as immigrante 'n gebied binnegekom het en die gesag van die bestaande owerheid aanvaar het, later self die mag oorgeneem en so koloniste geword het. In sommige gevalle is die immigrante as slawe of werkers deur ' $n$ koloniale owerheid ingevoer en het hulle mettertyd die corspronklike inwoners in aantal oortref. Met onafhanklikwording het hulle op demokratiese wyse die mag oorgeneem, terwyl die oorspronklike inwoners dan eintlik rog steeds deur 'n vreende groep oorheers is.

In die vroeë geskiedenis is daar verskillende voorbeelde van magsoorname deur immigrante, onder meer van Germane wat as soldate in die Wes$-133-$ 
Romeinse Ryk toegelat is en in die vylde cell behecr oor die ryk oorgeneem het en van Turke wat as slawe en solekate in die Arabiese ryke van die Nidde-Ooste grbruik is en wat in di: tiente en elfde couc dire may in die Abbasiedekalifat van ives-Asiö en twee cesue later uok in Egipte oorgeneem het (vgl. De Klerk, 1975:125; Hitti, 1970:671-682)

In die moderne tyd is daar ' $n$ hele aantal bekende gevalle. Op byna al die Karibiese eilande het afstammelinge van slawe wat vanaf die sestiende eeu deur die Westerse koloniserende monndhere uit Afrika ingevoer is, die mag in die hande gekry nadat die koloniale tydperk beindig is. In hierdie gebiede het die oorspronklike Indianebevolking egter feitlık verdwyn en is daar dus nie werklik meer' 'n koloniale situasie nie. Op Mauritius en Fiji, wat Britse kolonies was, is Indiese werkers ingevoer wat in albei gevalle die meerderheid van die bevolking geword het. Op Mauritius is die Indiese element sedert onafhanklikheid in 1968 die dominerende een, maar op $F i j i$ is 'n politicke stelsel aanvaar warrin die corspronklike Fijiane se regte verskans is en oorhecrsing deur die Indiërelement verhoed is (Lemon, 1980:107-109; 112-114). Nadat die Indiërs in die verkiesing van April 1987 tog ' $n$ onrwinning behaal het, het Fijiane in ' $n$ statsgreep die mag oorgeneem. Singapoer is in verdore voorbeeld. Terwyl dit 'n Britse kroonkolonin was, het talle Chinese na die gebied geimmigreer, en vandag vorm die Maleiers, wat vroeër die enigste groep daar was, slegs $15^{\circ}$ van die bevolking. Die stadstaat word hoofsaaklik deur die Chinese element beheer (vgl. NicFvedy en Jones, 1978: 195; Lemon, 1980: 115-120).

Moderne Israel, wat as 'n vestigingskolonie gesien kan word, kan nok as in geval van magsoorname deur iminigrante beskou word. Terwyl Palestina as mandaatgebied onder Britse grsag was, het talle Jorle na die. land geïmigreer en teen 1948 sowat 'n derde van die bevolking uitgrmakk (Smith, 1980:3(13-312). Hoewel die Balfourverklaring van 1917 voorsiening gemakk het vir 'n Joodse tuiste in Palestma, is in hocltemal Joodse staat oorspronklik nie beoog nie. In 19.18 het die Jocle in onafhanklike republiek uitgeroep in 'n gedeelln van Palestina warr hulle die meerderheid gevorm het. In die oorlog met die Arabiese lande wat daarop gevolg het, het 'n groot deel van die Arabiese inwoners van dic nuwe Joodse staat ook die gebied verlat. Dewr verdrre imnigrasic is -134 - 
die Joodse elcment versterk en tel hul sowat vyf miljoen tenoor ongeveer in miljoen Arabiere, wat as minderheidsgroep ten spyte van 'n demolratiese regeringstelsel in 'n ondergeskikte posisie beland het.

\section{Interne kolonialisme}

Die term interne kolonialisme, waarskynlik vir die eerste keer gebruik deur Lenin (Hechter, 1975:8), kom tans baie in wetenskaplike geskrifte voor. Dit is aanvanklik veral gebruik as teenstelling tot eksterne kolonialisme, waarby dan gedink is aan die groot Westerse koloniale ryke in Afrika en Asië, om kolonialisme binne die grense van een land aan te dui. Die term interne kolonialisme is daarby soms baie wyd verstaan, byvoorbeeld om die verhouding tussen die ryker en magtiger noordelike deel van die V.S.A. en die suidelike deel van die land te omskryf (Stone, 1979:255). Die inwoners van die noordelike en suidelike deel van die V.S.A. kan moeilik op etniese gronde van mekaar onderskei word en as inwoners van die noordelike deel na die suide emigreer en daar ' $n$ dominerende posisie beklee, kan nie werklik van kolonialisme, soos hierbo omskryf, gepraat word nie. Dit is natuurlik nie onmoontlik nie dat die teenstelling tussen die twee groepe in 'n situasie waar een dominerend is en 'n ander ondergeskik uiteindelik so groot word dat hulle as aparte etniese groepe beskou kan word. Hechter (1975) wil onder interne kolonialisme 'n situasie verstaan waar 'n dominerende kulturele kerngroep 'n periferiale kultuurgroep in dieselfde land domineer en materieel uitbuit, en hy beskryf die verhouding tussen Engeland en Wallis sedert die sestiende eeu as 'n interne koloniale verhouding. Hy meen dat veral die ontwikkeling van die kapitalistiese stelsel in Brittanje meegebring het dat die periferiale gebiede in Groot-Brittanje, nl. Wallis, Skotland en lerland, interne kolonies geword en dat arbeidsverdeling in hierdie gebiede op ' $n$ kulturele basis begin plaasvind het sodat Engelse vandag veral die hoër en Wallisers, Skotte en lere die laer posisies beklee. Hy sien die opkoms van etriese nasionalisme in Wallis en Skotland in die jongste tyd as ' reaksie op uitbuiting en ekonomiese ondergeskiktheid.

Die term is ook op situasies in baie ander lande toegepas (kyk Hind, 1984; McRobert, 1979; Reece, 1979; Palloni, 1979), onder meer op Suid-Afrika. Jie Suid-Afrikaanse regering se beleid teenoor die Transkei is onder meer 
deur Carter en Stultz (1967) as "domestic colonialism" gekarakterisner, terwyl $H$. Wolpe (2975:232) die hele nin-blanke Suid-Afrika as kolonie van blanke Suid-Afrika wil sien. Soos liechter hot hy in Minxistiese uitgangspurit en sien hy interne kolonialisme in die eerste plek as ekonomiese uitbuiting.

Hoewel die begrip interne kolonialisme nie oral in dieselfde sin gebruik word nie, sal dit hier gereserveer word vir die vorm van kolonialisme wat veral in moderne state voorkom waar een of meer etniese groepe in ' $n$ dominerende posisie is en ander in 'n ondergeskikte posisie. Slegs in gevalle waar daar reeds duidelik onderskeibaar groepe was voordat die een groep die ander begin domineer het, en die groepvorming dus nie gevolg was van oorheersing van een deel van 'n groep oor ' $n$ ander nie, kan die term interne kolonialisme gebruik word. Dominering van Engeland en die Engelse oor Wallis en Skotland sou dus wel as interne kolonialisne beskou kan word, maar nie dominering van die inwoners van die noordelike V.S.A. oor dié van die suide nie.

Interne kolonialisme is 'n vorm van die moderne tyd omdat dit veral meegebring is deur die konsep van moderne eenheidstate met vaste grense, wat nie noodwendig met etniese grense saamval nie, sodat minderheidsgroepe (of selfs in meerderheidsgroep) binne die staat in ondergeskikte posisis tennoor die kerngroep(e) kan raak. Vroeër het sulke situasies ook voorgekom, maar meesal binne groter politieke eenhede of ryke. Die state van vandag word as gelyke soewereine eenhede beskou en selfs die Sowjet-Unie, wat feitlik dieselfde grense as die ou Russiese koloniale ryk het, word nie meer as 'n koloniale ryk gesien nie. Situasies soos in Frankryk en Noorweë waar minderheidsgroepe, soos die Raske en Lappe, onderskeidelik voorkom, kan terugherlei word na volksverhuisings in die verre verlede, maar dit is veral met die ontwikkeling van Frankryk en Noorweë as moderne state dat die Baske en Lappe uiteindelik in die posisie van minderlieidsgrome gekom het

Daar is vandag feitlik geen staat ter wereld wat etnies heeltemal homogeen is en waar interne kolonialisme glad nie voorknm nie. Waar dis. minderheidsgroepe almal latere immigrante is, wat nadat die kerngroep beheer verkry het na die land gekom het, kan moeilik van interne $-136-$ 
kolonialisme gepraat word. In byna alle lande is daar egter onk etniese grompe wat net so lank of langer as die kelngroep in die land woonagtig is.

In Europa val staatsgrense nie heeltemal saam met etniese grense nie en is daar byvoorbeeld Duitssprekende Suid-Tirolers in die noorde van Italië en Sweedssprekendes in Finland, terwyl daar ook klein "resgroepe" oorgebly het, soos Baske in Frankryk en Spanje en Lappe in Noorweë en Finland. Daar was vroeër baie meer etniese verskeidenheid in Europa, maar die proses van staatsvorming het gepaard gegaan met 'n proses van etmiese en kulturele integrasie. In Frankryk van die sestiende ceu was daar byvoorbeeld groot verskille tussen Suid-en Noord-Franse en ook tussen Picardiërs, Normandiërs, Boergondiërs, ensovoorts, en min sprake van ' $n$ algemeen Franse etniese identiteit, maar vandag is dit nog net klein groepe met ' $n$ aparte etniese identiteit soos die Baske en Bretonners, asook groepies Vlaamssprekendes (in die noorde). Duitssprekendes (in die noordooste) en Italiaanssprekendes (in die suidooste) wat nie in alle opsigte as deel van die Franse etniese groep beskou kan word nie. Die proses van industrialisasie en verstedeliking het migrasie binne die lande bevorder en lei ook daartoe dat lede van die kerngroep na die gebied van minderheidsgroepe kom en streeksverskille verswak. Dit lyk dan ook of die geïndustrialiseerde lande dikwels etnies meer homogeen is as die minder geïdustrialiseerde lande (vgl. Seton-Watson, 1977). In die lande van die Derde Wêreld, waarvan die grense in die Westerse koloniale tyd hoofsaaklik sonder inagneming van etniese verskille bepaal is, is daar veel groter etniese verskeidenheid en is dit nie, soos in Europa, hoofsaaklik net klein minderheidsgroepe wat in 'n ondergeskikte posisie is nie. In hierdie lande is daar ook nie altyd 'n baie demokratiese regeringstelsel nie en is die dominerende groep nie altyd ' $n$ besliste ineerderheidsgroep nie, hoewel lande waar ' $n$ duidelike minderheidsgroep in die heersende posisie is, tans buite Suid-Afrika byna nie meer voorkoin nie (vgl. Hanf, 1983).

In al die vroeëre Westerse vestigingskolonies, dit wil sè die lande van Noold-, Sentraal-en Suid-Amerika, Australië, Nieu-Seeland en ook in Siberië is daar nog afstammelinge van die oorspronklike inboorlinge oor wat aparte etniese groepe gebly het en dus nou minderheidsgroepe in moderne state geword het. Dit kan dus ook as interne kolonialisme gesien 137 - 
word. Suid-Afrika is die enigste van die grool Westerse vestigingskolonies waar die koloniste self in die minderheid gebly het.

\section{Indirekte kolonialisme}

Die terme indirekte, semi- en neo-kolonialisme, asook ekononiese imperialisme kom, soos die term interne kolonialisme, dikwels voor in moderne wetenskaplike werke, veral van Marxistiese rigting, on aan te dui dat 'n bepaalde land ekonomies aflianklik van en ondergeskik aan 'n ander is, al is daar geen formele politieke oorheersing nie. Die term indirekte kolonialisme kan egter wyer gebruik word, naanlik vir alle verhoudinge van oorheersing en ondergeskiktheid tussen twee lande, state of groepe van 'n indirekte aard.

Verskillende vorme van indirekte kolonialisıne kom reeds sedert die Antieke Tyd voor. Egiptiese Faraos het in die vyftiende eeu voor Christus vorste in Sirië en Palestina onderwerp, hulle gedwing on in een van trou af te lé en hul kinders aan die Farao se hof te laat opvoed en 'n skatting te betaal (Kemp, 1978:43-45). Die onderworpe gebiede is nie direk by Egipte ingelyf nie en het eintlik satellietstate van Egipte geword. Die konings van Israel en Juda moes, volgens die Ou Testament, dikwels skatting betaal aan magtige buurvorste en het dus in ' $n$ posisie van satellietskap of vasaalskap van agtereenvolgens Aram, Assirië, Egipte en Babilonië geraak. In die tyd van die Franse Rewolusie en van Napolcon is in Nederland, Switserland en Italië republieke op Franse model gestig wat satellietstate van Frankryk geword het. (Later word hulle satellietkoninkryke met Napoleon se familielede as konings). Vandag word na die kommunistiese lando van Oos-Europa as satellietstate van die Sowjet-Unie verwys. Die Sowjet-Unie egter noem onder meer sommige republieke in Sentraal-Amerika satelliete van die V.S.A. en die term het 'n propagandamiddel geword wat nie altyd na ware satellietskap verwys nie. Dit is moeilik om definitiewe kriteria vas te stel. O. lattimore (aangehaal in Murphy, 1961:641) sien as 'n bepalende kenıncrk van dié verhouding dat die mag in die satellietstaat berus by 'n groep wat dell. inmenging van in vreemde moondheid aan bewind gekom liet en wat homself met die belange van daardie moondheid identifiseer ( $v g l$. ook Horvath, 1972). Dit kan seker ook insluit 'n situasie waar 'n groep wat 
voor inmenging reeds an bewind was die tvense van die vreemde moondheid begin uitvorr Iten einde hul pie posisies te behou of ondat hul geen ander nitwog sien nir). Aan die ander kant kan dit onk gebeur dat regerings wat met die hulp van vreemule moondlucde aan bewind gekom het, later 'n onafhanklike koers inslaan, soos die geval was in JoegoeSlawië. In Hongarye en Tsjeggo-Slowakye het die Sowjet-Unie ingegryp toe die owerhede daar hul los probeer mak het van die rigting wat aan hul vonrgeskryf is. Hierdie twee lande, asook Pole, Bulgarye, OosDuitsland, Mongolië en (in in mindere mate) Roemenië kan vandag nog as satellietstate van die Sowjet-Unic beskou word en die inwoners van hierdie gebiede verkeer hoofsaaklik in 'n ondergeskikte posisie teenoor die regering van die Sowjet-Unie, wat darvoor verantwoordelik is dat ' $n$ kommunistiese stelsel in die lande bestaan, ook al is daar geen Russe as oorheersers in die lande teenwoprdig nie.

'n Verwante vorm van indirekte kolonialisme, soms informele imperialisme genoem (Baumgart, 1982:5; Doyle, 1986:38), het in die periode van Westerse koloniale beheer in Afrika en Asië voorgekom, waar inheemse regerings in beheer gelaat is, maar 'n ambassadeur of verteenwoordiger van ' $n$ buitelandse regering die effektiewe mag gehad het, soos in Egipte in die laat negentiende en vroeë twintigste eeu, wat soms 'n "versluierde protektoraat" van Brittanje genoem is. 'n Ander verhouding wat as 'n vorm van indirekte kolonialisme gesien kan word, is die van hegemonie. Die term word meesal gebruik waar 'n groep state formeel onafhanklike bondgenote is, maar een in werklikheid die magtigste staat is wat die buitelandse beleid van die groep bepaal, terwyl die ander slegs op interne gebied hul eie sake kan reël. Reeds Thucydides, die Griekse historikus van die vyfde eell voor Christus, gebruik die term om die verhouding tirssen Sparta en sy bondgenote aan te dui (vgl. Doyle, 1986:40).

Jaar is vandag ook lande met regerings wat sonder die luulp van vreemde moondhede moeilik aan bewind sou bly, byvoorbeeld dié van Angola wat op Kubaanse troepe steun, maar nog nie heeltemal as satellietstate beskou kan word nie. Ander lande weer word beskou as deel van die Amerikaanse of Russicse invloedsfeer, maar dié term kan moeilik presies gedefinieer word, en dit het in die jongste verlede voorgekom dat lande op eic inisiatief in of uit so 'n invloedsfeer beweeg (byvoorbeeld Somalië en Ekwatoriaal-Guinea wat noue bande met die Sowjet-Unie gehad het en 
dit later verbreek het), sodat hier onk nie werklik van in koloniale verhouding sprake is nie.

Baie lande van die Derde Wèreld is vandag up ekmomiese gehiced in in posisie van afhanklikheid teenoor dié van die Westerse vèreld, ell verskillendes van hulle het 'n groot finansiële skuld by internasionale, Westerse gefinansierde monetere fondse en Westerse banke. Volgens die teorie van neo-kolonialisme wat teruggevoer kan word na Lenin (Fieldhouse, 1981:9) en deur Westerse Marxistiese skryivers (vgl. Brown, 1974) en derdewéreldpolitici soos K. Nkrumah (1965), wyer bekendheid gegee is, is die Westerse lande doelbewus daarop uit om hul voormalige kolonies deur ekonomiese middele in 'n ondergeskikte posisie te hou. Ondat grond, arbeid en ru-materiale goedkoper is in die land van din Derde Wéreld kan buitelandse investeerders daar groter ivinste behaal, en groot Westerse sake-ondernemings is besig on dic lande van Afrika, Asië en Latyns-Amerika uit te buit tot voordeel van die Weste. Hierdic teorieë word weerlè deur ekonome wat aantoon dat die Weste maar 'n klein deel van sy inkomste uit ondernemings in derdewèreldlande verkry (kyk o.m. Gann, 1975; Fieldhouse, 1981). Dit skyn asof die verdeling tussen ryk en arm lande nie besig is om te verdwyn nie, maar eerder skerper word. Die verarming van derdewèreldlande kan log moeilik as in belang van die Weste gesien word, en bring inee dat al meer ekonomiose hulp verleen moet word. Hoewel die ekonomiese afhanklikheid vall die armer lande hulle in sekere opsigte in 'n ondergeskikte posisie teenoor ryker lande plaas, is daar nie werklik oorheersing en kolonialisme nie. Die invloed van Westerse lande op die beleid van derdewereldregerings bly baie beperk.

In die huidige wereld is daar sulke nowe politieke, ekonomiese en kulturele verhoudinge tussen feitlik alle state ter wèreld dat gren staat volkome onafhanklik van ander kan optree nie. Die V.S.A. en die Sowjet-Unie is supermoondhede wat deur hul politicke mag en (veral wal die V.S.A. betref) ekonomiese en kulturele oorwig invloed op andor lande kan uitoefen. Die Westerse kultuur het alle samelewings ter wornld sterk beinvloed, en kan steeds wèreldwye invloed uitoefen. Hierdie kultuurbeinvloeding kan egter moeilik as 'n doelbewuste strewe yesien word on die wereld te oorheers, ook al word die term kulturele imperialisme of kulturele kolonialisme soms daarvonr gebruik. Iog kin 
hierdie dinge dui op nuwe vorme wat kolonialisme in die toekoms kan anneem

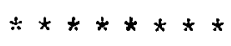

Kolonialisme is ' $n$ algemene verskynsel in die wèreldgeskiedenis, maar het op verskillende tye in verskillende vorme voorgekom. In die Oudheid en, veral wat Afrika en Amerika betref, tot in die sestiende eeu, was volksverhuisings war.skynlik die vorm wat die meeste voorgekom het. Ryksvestiging en die bestaan van ryke was ook sedert die Oudheid 'n algemene verskynsel in groot dele van die wèreld, en in Asië en Europa het ryke vanaf die tyd van die Persiese Ryk (in die sesde eeu voor Christus) in groot omvang bereik. Ook grensverskuiwing as kolonisasievorn het waarskynlik reeds lank tevore in die meeste wèrelddele voorgekom. Handelskolonies dateer eweneens reeds uit die Oudheid, maar het aanvanklik net in die Middellandse Seegebied voorgekom. Eers vanaf die sestiende eeu is handelsryke gevestig wat uit kolonies aan die kuste van al die groot oseane bestaan het. Hierdie handelskolonies het die weg gebaan vir Westerse vestigingskolonies wat uiteindelik die hele Amerikaanse vasteland, asook Australië en die suidelike deel van Afrika omvat het. In die laat negentiende en vroeë twintigste eeue is koloniale ryke gevestig warbinne dele van verskillende vastelande onder een oppergesag verenig is, mar hierdie ryke het maar kortstondig bestaan, en vandag kom kolonialisme net op kleiner skaal, maar nie noodwendig in minder gebiede as vroeër nie, voor. Met die ontwikkeling van moderme state in Europa, en later in die res van die wêreld, het interne kolonialisme sy verskyning gemaak en kan vandag as die mees algemene vorm van kolonialisme beskou word. In die huidige wèreld, wat bestaan uit 'n aantal state met vaste grense wat formeel as van gelyke status beskou word, mar waar naas magtige state van reuse-onvang, soos die Sowjet-Unie en die V.S.A., ook miniatuurstaatjies met net enkele duisende inwoners bestaan, is indirekte kolonialisme, waar in staat formeel onafhanklik, maar in wese onderhorig is aan 'n ander een, ' $n$ vorm wat inoontlik ' $n$ al groter rol kan begin speel.

Ook in die Suid-Afrikanse geskiedenis kan voorbeelde van die meeste vorms wat in hierdie artikel bespreek is, gevind word. Volksverhuisings het in die vroeë geskiedenis warrskynlik baie voorgekom en het tot in -141 - 
die negentiende eeu voortgeduur. Die Kaapse verversingspos wat in die sewentiende eeu deur die Nederlanders gestig is, was aanvanklik deel van 'n uitgestrekte handelsryk, en het self uitgegroei tot in vestigingskolonie. Deur 'n proses van grensverskuiwing het die grense van hierdie kolonie al verder uitgebrei en trekbewegings van die koloniste het daarna tot die vestiging van nuwe blank-beheerde state in die oostelike helfte van Suid-Afrika gelei. In die vroeë negentiende eeu is ook ryke gevestig, onder meer diè van die Zoeloes en Matabeles, maar het as gevolg van die koms van die Voortrekkers slegs kortstondig bestaan. Die Kaapkolonie, en later die hele Suid-Afrika, het ondertussen deel geword van die Britse wêreldryk. Hoewel Suid-Afrika vandag soms gesien word as die laaste belangrike oorblyfsel van Westerse kolonialisme het dit, net soos die state wat tans in Noord-en Suid-Amerika bestaan, deur Westerse koloniale uitbreiding vanaf die vyftiende eeu tot stand gekom. Net soos in daardie lande kom in Suid-Afrika interne kolonialisme vandag as die vernaamste vorm van kolonialisme voor. Die verskil tussen die situasie in Suid-Afrika en in die Amerikaanse state is hoofsaaklik net 'n verskil in die getalsverhouding tussen koloniste en inboorlinge en (in vergelyking met Latyns-Amerika) ' $n$ verskil in die mate van integrasie wat daar tussen die koloniserende en gekoloniseerde groepe plaasgevind het.

Hoewel kolonialisme vandag in ander vorme voorkom as in die Oudheid, het dit as verskynsel geensins verdwyn nie. Dit is wel waar dat 'n kleiner deel van die mensheid as wat 'n eeu gelede die geval was, vandag in een of ander vorm van koloniale onderhorigheid verkeer. Hieruit kan egter moeilik afgelei word dat kolonialisme besig is om te verdwyn en dat dit uiteindelik nie meer sal voorkom nie. Solank as wat die mensheid in verskillende etniese groepe verdeeld bly en groepe darna strewe om hul mag en rykdom ten koste van ander groepe uit te brei, sal kolonialisme waarskynlik bly voorkom en in die toekoms sou dit weer groter afinetings kan aanneem as wat tans die geval is. 
BRONNE

ARMSTRONG, J. 1982. Nations before ethnicity. Los Angeles: University of California.

BILLINGTON, R.A. 1949. Westward expansion: a history of the Amer-

ican frontier. New York : McMillan.

BROWN, M.E. 1974. The economics of imperialism. Londen : Penguin.

CARTER, GWENDOLEN M. en STULTZ, N.M. 1976. South Africa's

Transkei: the politics of domestic colonialism. Londen : Heinemann.

CURTIN, P.D. 1984. Cross-cultural trade in world history. Cambridge : University.

DE KLERK, P. 1975. Blywende kolonisasie? Potchefstroom : Pro Rege.

DOYLE, M.W. 1986. Empires. Ithaca : Cornell University.

EMERSON, R. 1968. Colonialism. (In International encyclopedia of the social sciences, deel 3. Londen : McMillan: 1-5).

ETHERINGTON, N. 1984. Theories of imperialism: war, conquest and capital. Londen : Croom Helm.

FIELDHOUSE, D.K. 1981. Colonialism, 1870 - 1945. Londen : Weidenfeld $\varepsilon$ Nicolson.

GAI.BRAITH, J.K. 1960. The "turbulent" frontier as a factor in British expansion. Comparative studies in society and history, 2:150-168.

GANN, L.H. 1975. Neo-colonialism, imperialism and the "new class". Menlo Park (Cal.) : Institute for humane studies.

GERHARD, D. 1959. The frontier in comparative view. Comparative studies in society and history, 1:205-229. 
HAMMOND, N.G.L. 1976. A history of Greece to 322 B.C. Oxford: Clarendon.

HANF, T, Lessons which are never learnt: minority rule in comparative perspective (In Adam, H. (red.) South Africa, the limits of political reform. Leiden : Brill : 22-23.)

HAWKES, J. 1976. The atlas of early man. Londen: McMillan.

HECHTER, M. 1975. Internal colonialism; the Celtic fringe in British national development, 1536 - 1966. Londen : Routledge \& Kegan Paul.

HIND, R.J. 1984. The internal colonial concept. Comparative studies in society and history, 26(3):543 - 568 .

HITTI, P.K. 1970. The Arabs. Londen : McMillan.

HORVATH, R.J. 1972. A definition of colonialism. Current anthropology, 13:45-57.

KEMP, B.J. 1978. Imperialism and empire in new kingdom Egypt (1575 - 1087 B.C.). (In Garnsey. P.D. en Whittaker, C.R. (reds.). Imperialism in the ancient world. Cambridge : University: 7-57.)

KHAZANOV, A.M. 1984. Nomads and the outside world. Cambridge: University.

KOEBNER, E. en SCHMIDT, H.D. 1976. Imperialism; the story of and significance of a political word. Cambridge : University.

KOHN, H. 1958. Reflections on colonialism. (In Strauss-Hupé, R. en Hazard, H.W. (reds.). The idea of colonialism. Londen: Stevens: 2-16.)

LAMAR, H. en THOMPSON, L., (reds.) 1981, The frontier in history. North America and Southern Africa compared. New Haven: Yale. 
LEE, J. 1978. Nigration and expansion in Chinese history. (In McNeill, W.H. en Adams, R.S., (reds.). Human migration: : patterns and policies. Bloomington : Indiana University: 20-47.)

LEMON, A. 1980. Asian overseas settlement in the nineteenth and twentieth centuries. (In Lemon, A. en Pollock, N. (reds.). Studies in overseas settlement and population. Londen : Longman: 103-126.)

MCEVEDY, C. en JONES, K. 1978. Atlas of world population history. llarmondsworth : Penguin.

MCNEILL, W.H. 1978. Human migration: a historical overview. (In McNeill, W.H. en Adams, R.S. (reds.). Human migration: patterns and policies. Bloomington : Indiana University: 3-19.)

MCROBERTS, K. 1979. Internal colonialism: the case of Quebec. Ethnic and social studies, 2(3):293-318.

MOMMSEN, $W$. 1981. Theories of imperialism. Londen : Weidenfeld $\varepsilon$ Nicolson.

MURPHY, G.G.S. 1961. On satelliteship. Journal of economic history, $21(4): 641-651$.

NKRUMAH, K. 1965. Neo-colonialism, the last stage of imperialism. Londen : 1965.

PALLON1, A, 1979. Internal colonialism or clientelistic politics? The case of Southern Italy. Ethnic and social studies, 2(3):360-377.

REECE, J.E. 1979. Internal colonialism: the case of Brittany. Ethnic and social studies, 2(3):275-291.

SALMON, E.1. 1969. Roman colonisation under the republic. Londen : Thatnes \& Hudson.

SETON-WATSON, H. 1977. Nations and states; an inquiry into the origin of nations and the policies of nationalism. Londen : Methuen.

$-145-$ 
SMITH, G. 1980. Jewish settiement in Palestine between 1882 and 19.48: its role in the transformation of a landscape and in the foundation of the state. (In Lemon, A. en Pollock, N. (reds.). Studies in overscas settlement and population. Londen : Longman: 291-321.)

STONE, J. 1979. Introduction; internal colonialism in comparative perspective. Ethnic and social studies, 2(3):255-259.

THORNTON, A.P. 1965. Doctrines of imperialism. New York: Wiley. WEBB, W.P. 1952. The great frontier. Boston: Houghton Mifflin

WEISSLEDER, W. (red.) 1987. The nomadic alternative; modes and models of interaction in the African-asian deserts and steppes. Den Haag : Mouton.

WOLPE, H. 1975. The theory of internal colonialism; the South African case. (In Oxaal, t., Barnett, T. en Booth, D. (reds.). Beyond the sociology of development. Londen : Routledge: 229-252.) 